\section{ニジマスにおけるヘルペス ウイルス病の発生}

降幡 充 $^{*}$ ・細江 昭 ${ }^{1} \cdot$ 武居 薰 ${ }^{1}$. 小原昌和 ${ }^{1,3} \cdot$ 中村 淳 ${ }^{1} \cdot$ 本西 晃 ${ }^{1}$ 吉水 守 ${ }^{2}$

(2002年 7 月 15日受付)

\section{Outbreak of Salmonid Herpesviral Disease in Cultured Rainbow Trout}

\author{
Mitsuru Furihata ${ }^{1 *}$, Akira Hosoe ${ }^{1}$, Kaoru Takei ${ }^{1}$, \\ Masakazu Kohara ${ }^{1,3}$, Jun Nakamura ${ }^{1}$, \\ Akira Motonishi ${ }^{1}$ and Mamoru Yoshimizu ${ }^{2}$ \\ ${ }^{1}$ Nagano Prefectural Fisheries Experimental Station, \\ Nakagawate 2871, Akashina, \\ Nagano 399-7102, Japan \\ ${ }^{2}$ Graduate School of Fisheries Sciences, Hokkaido \\ University, Minato 3-1-1, Hakodate, \\ Hokkaido 041-8611, Japan \\ ${ }^{3}$ Horticulture \& Special Products Division, Nagano \\ Prefectural Government, Minaminagano \\ Habashita 692-2, Nagano, Nagano \\ 380-8570, Japan
}

(Received July 15, 2002)

\begin{abstract}
From February 2000 to January 2001, epizootics occurred in cultured rainbow trout Oncorhynchus mykiss weighing $12-1,503 \mathrm{~g}$ at 18 fish farms in Nagano Prefecture, Japan. A virus was isolated from diseased fish in RTG-2 cells with a CPE characterized by syncytia. High infectivity titers were demonstrated in the main internal organs and multiple necrotic foci were observed in the liver. The virus was identified as salmonid herpesvirus 2 by serological tests and PCR. Based on these results, the epizootic was diagnosed as salmonid herpesviral disease. In more than $80 \%$ cases, the outbreaks were linked with introductions of live fish.
\end{abstract}

Key words: salmonid herpesviral disease, Oncorhynchus mykiss, salmonid herpesvirus 2, rainbow trout, SaHV-2

日本におけるサケ科魚類のヘルペスウイルスは1972年

\footnotetext{
1 長野県水産試験場

2 北海道大学大学院水産科学研究科

${ }^{3}$ 現所属：長野県園芸特産課

* Corresponding author

E-mail: mfurihata@ nifty.com
}

及び1974年に十和田湖の孵化場で死亡したヒメマス稚魚 から ${ }^{1)}$, 次いで1978年には北海道のサクラマスの卵巣空 液からも分離された2)。その後, 養殖ヤマべ (Oncorhynchus masou）の口部腫瘍（基底細胞癌）や養殖ヒメ マス（O. nerka）の大量死をはじめ ${ }^{3)}$ ，海面養殖ギンザ ケ (O. kisutch) 大型魚の死亡あるいは生残魚での口部 腫瘍等の産業被害が報告されたが4)，防疫対策の徹底に より北日本ではほぼ終息した5)。ニジマスのヘルペスウ イルス病は1992年に北海道の養殖ニジマスに最初に発生 し，成魚が死亡することから経済的損失が大きかったが， 防疫対策の実施により発生件数は激隇した。しかし，近 年，再び本州中部に発生が見られ6)，ニジマスの主産県 である長野県では，1999年に本ウイルス病に似た症状を 有するニジマスの大量死亡が発生し，翌年には複数の養 殖場に広がった。本研究では死亡原因と感染原因を明ら かにするため，養鱒場業者への聞き取り調查を行うとと もに, 病魚の病理学的検討を行った。

\section{材料及び方法}

2000年 2 月から翌年 1 月に長野県の18養鱒場でニジ マスの異常大量死亡が発生した。養鱒場主からの聞き取 りによって発生状況及び感染源を調查するとともに，2 養鱒場（A，B）の7発病群について, 飼育尾数, 体重, 流 行期間，死亡率及び水温を調査した。

これら症例から採取した病魚106尾の外観及び内臓所 見を観察し，外部寄生虫検査及びウイルス検査を行い， その内の98尾について細菌検査を，68尾について真菌検 查を行った。さらに，1養䲡場の瀕死魚 5 尾（23〜 43 g BW）については，病理組織検查，分離ウイルスの中和 試験及び PCR による Oncorhynchus masou virus (OMV) 特異遺伝子の検出, 主要臟器のウイルス感染価 の測定も行った。外部寄生虫検査は鰖, 体表及び鰓を検 鏡した。細菌検査は腎臓よりトリプトソーヤ寒天培地を 用いて常法に従い細菌分離を行い, $20^{\circ} \mathrm{C}$ で 7 日間の培 養を行った。真菌検査はIChthyophonus hoferi 感染の有 無を腎臓及び肝臓組織の圧扁標本を作製し検鏡した。ウ イルス検查は抗生物質 (penicillin-G 800 I.U./mL, streptomycin $800 \mu \mathrm{g} / \mathrm{mL}$, mycostatin 200 unit $/ \mathrm{mL}$ ) 入り Hanks' Balanced Salt Solution で100倍に希釈した腎蔵ホモジ ネート上清を $15^{\circ} \mathrm{C} て ゙ 3$ 時間静置した後, RTG-2 細胞に 接種し, $15^{\circ} \mathrm{C} て ゙ 14$ 日間 CPE 発現の有無を観察した。

病理組織検查は肝臓を $10 \%$ 中性緩衝ホルマリン液で固 定し, 厚さ $4 \mu \mathrm{m}$ のパラフィン切片を作製し, H-E 染色 後光顕観察した。中和試験は（社）日本水産資源保護協 会から分与を受けた抗 OMV 家鬼血清 $\left(\mathrm{ND}_{50}=1: 140\right)$ を 7 倍に希釈し, RTG-2 細胞を用いて $50 \%$ 終末点法に よる定性試験によって行った。OMV 特異遺伝子検出用 $\mathrm{PCR}^{7)}$ は CPE が現れた培養細胞から行い，陽性対照と 
して OMV 00-7812株を用いた。主要臓器のウイルス感 染価は, 腎蔵, 肝臓, 脾獩及び脳についてRTG-2 組胞を 用いた50\%終末点法により算出した。

\section{結果及び考察}

異常大量死亡は $12 \mathrm{~g} の 0$ 年魚から1,503 g の親魚まて 見られ，通年発生していた。18養䱾場に扔ける発病サイ ズは $100 \mathrm{~g}$ 以下が5養鯈場（28\%），100 1,000 g が 6 養鱒場（33\%），1,000 g 以上が 7 養鱒場（39\%）であっ た。感染原因は近県や県内養鱒場からの活魚の導入によ るものが10養蹲場（56\%），同一水系による水平感染が 5 養鱒場（28\%），不明が 3 養鰌場（16\%）であった。

$\mathrm{A}$ 養鱒場に㧍ける 6 発病群の死亡は 4 月上旬から 7 月 下旬に見られ，流行期間は80〜118日閒，累積死亡率は 33.6 77.0\%であった。它の期間の水温は8.1 20.6 ${ }^{\circ} \mathrm{C}$ で あった。 $\mathrm{B}$ 養鰌場では 9 月下旬（水温 $12.5^{\circ} \mathrm{C}$ ) $40 \mathrm{~g}$ の魚が発病し，2001年 1 月中旬（同8.2 $\left.{ }^{\circ} \mathrm{C}\right)$ までの107日 間死亡が続いたことから，飼育群は処分された。この間 の累積死亡率は41.4\%であった（Table 1)。

外観所見として，体表に扮ける斑点状の退色症状，鰓 の軽度の退色及び鰓弁の出血が観察された。発病群全体 では潰湯形成を伴う個体は少なかった。内獩所見は朋臓 が退色し，一部の魚の肝臓に自斑の形成が見られた。气 の他, 腹腔内脂肪の発赤, 腸の発赤が観察された（Fig. 1)。発病群や耐過群に腫瘍を形成した個体は確認されな かった。

外部寄生虫検查では, 死亡原因と考えられる寄生虫は 認められなかった。また，細菌及び真菌検査では，病魚
98尾中 3 尾から Streptococcus iniae が分離され，68尾 中 4 尾に I. hoferiが観察された。ウイルス検査では, 106 尾中 85 尾 (80\%) 加 RTG-2 細胞に多盉巨細胞の形成 を特徴とする CPE 者すウイルスが分離された。分離 ウイルスは RTG-2 細胞で継代が可能であった。

中和試験に用いた分離ウイルス 5 秼はいずれも抗 OMV 血清添加区で $2 \log _{10}$ 以上の感染価隇少が認められ, 中和陽性と判断された。また，PCR では OMV 00-7812 株と同じ位置 (439bp) に1本のDNA セグメントが増 幅された（Fig. 2)。病理組織検查では肝臓の寒質組胞に 核崩壊を伴った多数の壤死病巣が観察された（Fig３）。 主要蔵器のウイルス感染価は, 肝蔵が10 $0^{5.6-8.3}$, 腎臟が $10^{4.9-8.4}$, 脾臓が $10^{5.4-8.4}$, 脳が $10^{5.8-7.7} \mathrm{TCID}_{50} / \mathrm{g}$ であっ た。

1999年から長野県で発生したニジスの異常な大量死 の原因老調查した結果，異常大量死は通年発生して㧈り， $100 \mathrm{~g}$ 以上の魚の発症が全体の70\%以上占めた。また， $400 \mathrm{~g}$ 以上の大型魚の累積死亡率は70\%以上と高かった。 主な病徽は鰓の軽度な退色と鰓弁の出血，肝臟の退色並 びに腹腔内脂肱と腸の発赤であった。

大量死の原因と考岳られる外部寄生虫は認められず, S. iniae 及び I. hoferi は検出頻度が低いこと亦ら直接の 死因ではないと判断された。一方，OMVの感染奉験病魚 やギンザケのヘルペスウイルス病魚で見られる肝臓の巣 状壊死像 ${ }^{2,4)}$ が一部の病魚に見られ，ウイルス検查では 80\%の病魚に扔いてへルペスウイルスに特徴的な多核巨 細胞を形成するCPE が観察された。そして，分離ウイ ルスは抗 OMV 家鬼血清により中和され，PCRにより

Table 1. Results of epizootiological survey of salmonid herpesviral disease in rainbow trout

\begin{tabular}{cccccc}
\hline Fish farm & $\begin{array}{c}\text { No.of fish reared } \\
\text { in the pond }\end{array}$ & $\begin{array}{c}\text { Mean body } \\
\text { weight }(\mathrm{g})\end{array}$ & $\begin{array}{c}\text { Epizootic period } \\
\text { (Duration in day) }\end{array}$ & $\begin{array}{c}\text { Cumulative } \\
\text { mortality }(\%)\end{array}$ & $\begin{array}{c}\text { Water } \\
\text { temperature }\left({ }^{\circ} \mathrm{C}\right)\end{array}$ \\
\hline A & 3,500 & 110 & $2000.5 .12-7.31(80)$ & 37.7 & $10.5-20.6$ \\
A & 2,600 & 190 & $2000.4 .20-7.19(90)$ & 34.5 & $9.4-18.8$ \\
A & 3,900 & 190 & $2000.4 .28-7.19(82)$ & 33.6 & $9.4-18.8$ \\
A & 500 & 420 & $2000.4 .12-7.5(84)$ & 77.0 & $8.7-18.8$ \\
A & 700 & 800 & $2000.4 .12-7.4(83)$ & 70.1 & $8.7-18.8$ \\
A & 1,000 & 1,000 & $2000.4 .4-7.31(118)$ & 72.1 & $8.1-20.6$ \\
B & 75,000 & 40 & $2000.9 .29-2001.1 .14(107)$ & 41.4 & $8.2-12.5$ \\
\hline
\end{tabular}

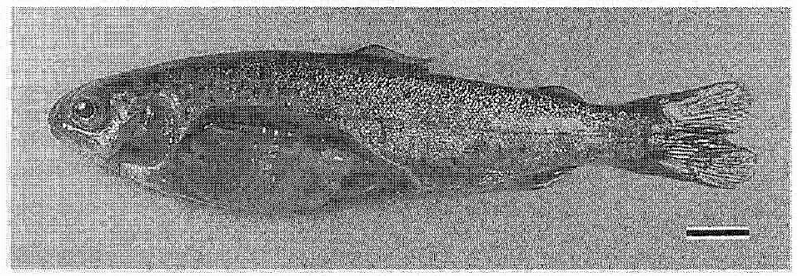

Fig. 1. Diseased rainbow trout $(16.1 \mathrm{~g} \mathrm{BW})$, showing white spots in the liver. Bar $=1 \mathrm{~cm}$

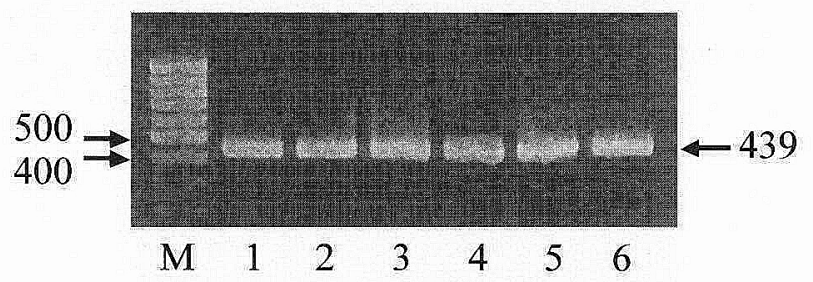

Fig. 2. Agarose gel electrophoresis of PCR amplification products of 5 virus isolates from diseased fish and OMV strain 00-7812. Lanes: $M$; DNA molecular weight marker, 1-5; virus isolates from diseased fish, 6; OMV strain $00-7812$ 


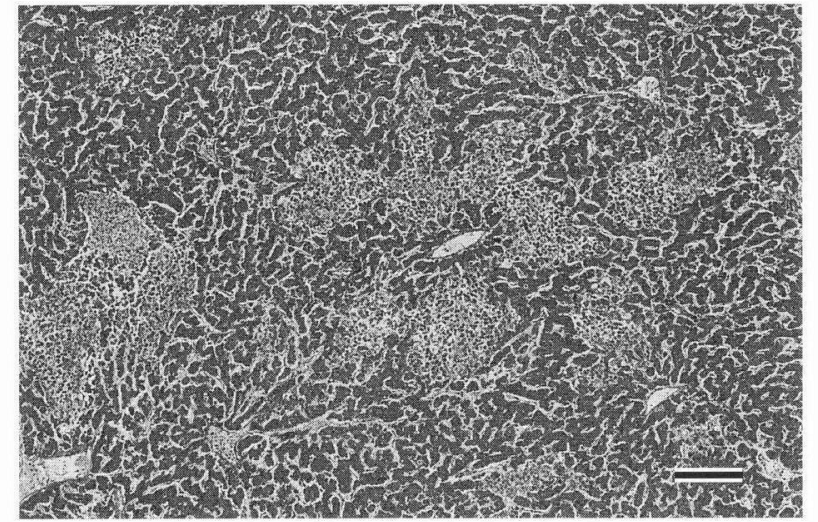

Fig. 3. Multiple foci of severe necrosis in the liver. H-E stain, Bar=200 $\mu \mathrm{m}$

OMV 特異遺伝子が増幅されたことから，本ウイルスは salmonid herpesvirus 2 と判断された。主要臟器のウイ ルス感染価は10 $4.9-8.4 \mathrm{TCID}_{50} / \mathrm{g}$ と高く, 本病はサケ科 魚類のヘルペスウイルス病と骖断された。

北海道の養鱒場で初めて発生したニジマスのヘルペス
ウイルス病が本州へ伝播した原因は定かでない。長野県 下の場合，発生のあった18養鱒場の内10養鰌場の感染源 は購入した活魚であった。また,これらと同一水系のた

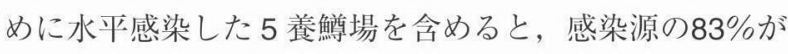
活魚の移動に起因していた。恐らく本州の主産県に被害 が拡大した原因も活魚の移動によると推定される。

\section{文献}

1) Sano, T. (1976) : Fish Pathol., 10, 221-226. 2) Kimura, T., M. Yoshimizu, M. Tanaka and H. Sannohe (1981): Fish Pathol., 15, 143-147. 3) Kimura, T. and M. Yoshimizu (1991): Annual Rev. Fish Disease, 1, 6782. 4) Kumagai, A., K. Takahashi and H. Fukuda (1994): Fish Pathol., 29, 127-134. 5) Yoshimizu, M., H. Fukuda, T. Sano and T. Kimura (1995): Vet. Res., 26, 486-492. 6) Yoshimizu, M. and T. Nomura (2001): Bull. Natl. Res. Inst. Aquacult., Suppl., 5, 11-14. 7) Aso, Y., J. Wani, D. A. S. Klenner and M. Yoshimizu (2001): Bull. Fish. Sci. Hokkaido Univ., 52, 111-116. 